\title{
Potassium silicate as a resistance elicitor in sweet corn yield traits under water stress
}

\section{Silicato de potasio como elicitor de resistencia en las características de rendimiento de maíz dulce bajo estrés hídrico}

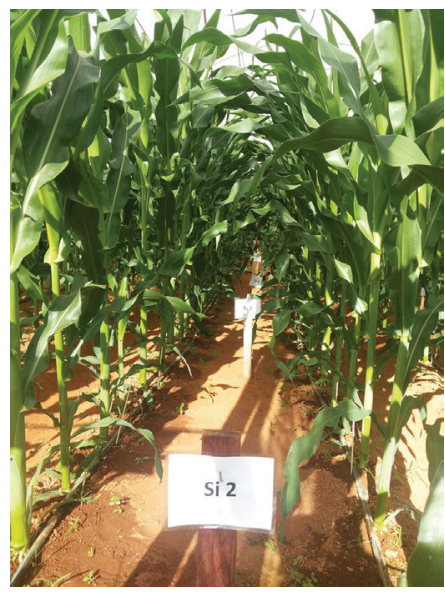

\section{AUSBIE L.G. ARAÚJO'1 \\ AMANDA M. DE ALMEIDA² \\ JOÃO DE J. GUIMARÃES² \\ FERNANDO S. DE CANTUÁRIO² \\ LEANDRO C. SALOMÃO 2 \\ AURÉLIO R. NETO' \\ JOSÉ M.Q. LUZ \\ ALEXANDRE I.A. PEREIRA2,4}

Sweet corn plants submitted to potassium silicate and soil water tensions.

Fhoto: J.J. Guimarães

\section{ABSTRACT}

Plant water stress is a major problem in the Cerrado biome of Brazil. Dry periods and random climatic events cause quality and yield losses in sweet corn plants. Compounds, such as silicon ( $\mathrm{Si}$ ), are being studied to reduce the negative impacts of water stress on agricultural crops. Further tests may allow farmers to increase the use of silicon-based compounds. The objective of this study was to evaluate the production parameters of the sweet corn (Zea mays var. saccharata) (Poaceae) Tropical Plus ${ }^{\circledast}$ hybrid with water stress and potassium silicate doses applied with foliar spraying. A randomized block design with four soil water tensions (15, 30, 45 and $60 \mathrm{kPa})$ and four potassium silicate doses $\left(0,6,12\right.$ and $\left.24 \mathrm{~L} \mathrm{ha}^{-1}\right)$ was used in a greenhouse. The studied factors, alone or in interaction with each other, did not affect most of the sweet corn yield parameters. The hypothesis that these results may have been partially affected by the presence of silicon are discussed. The sweet corn plant yield was affected mainly by the soil water tension of $60 \mathrm{kPa}$.

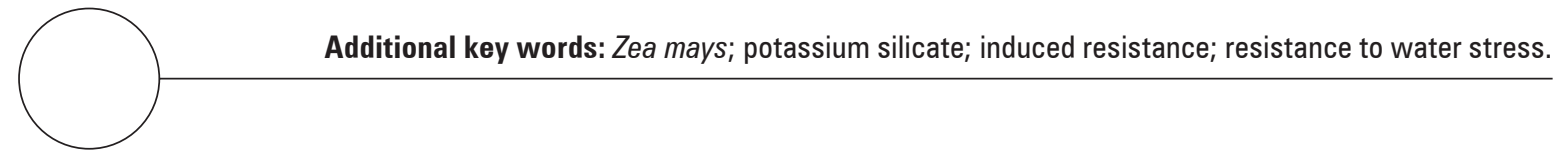

Instituto Federal Goiano, Campus Rio Verde Campus, Goiás (Brazil). ORCID, Araújo, A.L.G.: 0000-0001-6493-5727; ORCID Neto, A.R.: 0000-0003-0517-122

2 Instituto Federal Goiano, Campus Urutaí, Urutaí, Goiás (Brazil). ORCID, Almeida, A.M.: 0000-0003-2559-125X; ORCID Guimarães, J.J.: 0000-0001-6710-7185; ORCID Cantuário, F.S.: 0000-0002-8052-4861; ORCID Salomão, L.C.: 0000-0001-9436-1488; ORCID Pereira, A.I.A.: 0000-0001-7957-6691

3 Universidade Federal de Uberlândia, Campus Umuarama, Uberlândia (Brazil).

4 Corresponding author. aiapereira@yahoo.com.br 


\section{RESUMEN}

El estrés hídrico en la planta es un problema importante en el bioma Cerrado de Brasil. Los períodos secos y los eventos climáticos aleatorios causan pérdidas de calidad y productividad en las plantas de maíz dulce. Compuestos como el silicio ( $\mathrm{Si}$ ), pueden ser estudiados para reducir los impactos negativos del estrés hídrico en los cultivos agrícolas. Pruebas adicionales pueden permitir a los agricultores aumentar el uso de compuestos a base de silicio. El objetivo de este trabajo fue evaluar los parámetros de producción de maíz dulce (Zea mays var. Saccharata, híbrido Tropical Plus ${ }^{\circledR}$ ) con niveles de estrés hídrico y dosis de silicato de potasio aplicadas por pulverización foliar. El diseño experimental fue un diseño de bloques al azar con cuatro tensiones hídricas en el suelo (15, 30, 45 y $60 \mathrm{kPa}$ ) y cuatro dosis de silicato de potasio $\left(0,6,12\right.$ y $\left.24 \mathrm{~L} \mathrm{ha}^{-1}\right)$ en invernadero. Los factores estudiados solos o en interacción no afectaron la mayoría de los parámetros de producción de maíz dulce. Se discute la hipótesis de que estos resultados pueden haber sido parcialmente afectados por la presencia de silicio. El rendimiento de la planta de maíz dulce se vio afectado principalmente por el estrés hídrico del suelo a $60 \mathrm{kPa}$.

Palabras clave adicionales: Zea mays; silicato de potasio; resistencia inducida; resistencia a la sequía.

Received for publication: 08-04-18 Accepted for publication: 29-03-2019
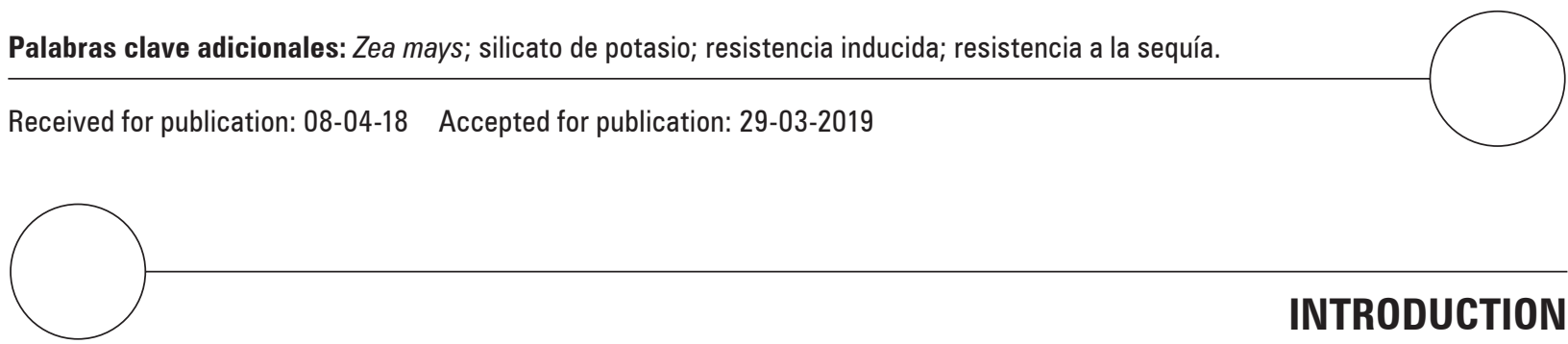

INTRODUCTION

The State of Goiás, one of the largest corn producers in Brazil (Okumura et al., 2013), has been experiencing droughts and poor rain distribution (Brunini et al., 2001). The quality and productivity of this plant, with significant economic and social importance, have been affected (Berlato et al., 2005). Climatic effects, such as El Niño (Li et al., 2011), have caused more frequent dry periods and water stress condition (Doto et al., 2015). Corn farmers are irrigating their crops, but at high costs (Montero et al., 2013). In addition, rainfall scarcity has reduced water levels in reservoirs.

Sweet corn (Zea mays var. saccharata) (Poaceae) cultivation is increasing in Brazil (Teixeira et al., 2001) in order to supply agroindustries that process raw material for commercialization. This has increased the income of small and medium sized farmers and jobs on a macro scale (Barbieri et al., 2005). The sweet corn cultivation system in the State of Goiás has prospects for expansion since Brazilian agriculture is one of the major producers of common corn (Zea mays) in the world (Okumura et al., 2013). Syngenta dominates the sweet corn seed market in Brazil; the Tropical Plus ${ }^{\circledR}$ hybrid has the highest commercialization.

Zea mays is tolerant to water deficits during the vegetative phase, but exhibits high sensitivity if this condition prevails during the reproductive phase (Santos et al., 1998). Therefore, technologies that amortize the effects of water stress in economically and socially important plants, such as sweet corn, should be assessed. Silicate fertilization has been viewed as a technology that mitigates the negative effects of stress factors on plants (Ma and Yamaji, 2006) although it is not yet widely used by Brazilian farmers. Silicon has been used as an elicitor of resistance in plants under conditions of abiotic stress, such as saline, heavy metal poisoning or water stress. The accumulation of $\mathrm{Si}$ in transpiration organs causes the formation of a double layer of silic, with a subtle decrease in opening of the stomata, reducing leaf transpiration, which restricts the loss of water without influencing growth (Oliveira and Castro, 2002).

The corn plant has a natural ability to respond favorably after exposure to exogenous $\mathrm{Si}$ sources because it accumulates this element (Takahashi et al., 1990). The concentration of Si in this plant is linked to aerobic respiration, increasing its accumulation in soils or hydroponic solutions that hold considerable amounts of silicon. In summation, the genes ZmLsi1 and $Z \mathrm{mLsi} 6$ present in corn plants are responsible for the transport of Si soil solutions to root cells and xylem cells for the balance of plants, respectively, demonstrating the adaptability of this plant to Si (Mitani et al., 2009).

The beneficial effects of Si on corn plants in Brazilian agricultural are still neglected in the field, while 
increasingly scientific results have proven the high adaptability of these plants. The fact that Brazilian soils, especially those located in the Cerrado biome, are poor in soluble $\mathrm{Si}$ accessible to plants (Korndörfer et al., 2004) may explain this fact. Farmers often avoid using silicate fertilizers for fear of increasing production costs. Nevertheless, the use of fertilizers as an exogenous source of $\mathrm{Si}$ in sweet corn, via soil or foliage spraying, has great potential for stimulating level of resistance to water stress (Marques et al., 2016). The outcomes of the present study may encourage the use of silicate fertilization in corn plants under water stress.

The aim of the present study was to evaluate responses in the production parameters of sweet corn hybrid Tropical Plus ${ }^{\circledR}$ under water stress with doses of potassium silicate sprayed on the leaves.

\section{MATERIAL AND METHODS}

This experiment was carried out in an experimental area of the "Instituto Federal Goiano-Campus Urutaí" located at Fazenda Palmital, rural region of the city of Urutaí, Goiás State (Brazil). Experimental site is located at $17^{\circ} 29^{\prime} 10^{\text {"S }}$ and $48^{\circ} 12^{\prime} 38^{\prime \prime} \mathrm{W}$, at 697 m a.s.1.
The sweet corn plants were cultivated in a greenhouse, simple arc type, with an East-West orientation, made with a metallic structure and the dimensions: $30 \mathrm{~m}$ length, $7 \mathrm{~m}$ width, and $6.2 \mathrm{~m}$ arc height, covered with a low-density polyethylene (LDPE) film (0.15 $\mathrm{mm}$ thick) and a anti-aphid mesh on the sides.

The climate of the region is classified as tropical at altitude with a dry winter and rainy summer, Cwb type according to the Köppen classification. The soil of the experimental area was classified as Dystrophic Yellow Red Latosol (Embrapa, 1999) with a sandy loam texture and physical and chemical characteristics presented in Table 1. For the physical and chemical analysis of the soil, five samples were collected inside the greenhouse. The samples were homogenized for a representative composite sample using the 0 to $20 \mathrm{~cm}$ and 20 to $40 \mathrm{~cm}$ layers of depth. The soil samples were sent to the "Laboratório Agropecuário Ltda. (SOLOGRIA)" in the city of Goiânia, State of Goiás, to obtain the technical report.

The sweet corn Tropical Plus ${ }^{\circledR}$ hybrid was used (Syngenta Seeds Ltda), provided by the company Conservas Oderich SA (Orizona, Goiás), which produces canned vegetables, including sweet corn, and who supplied the technical information needed for the sweet corn plants. The sowing was performed on April 30, 2015 with a spacing of $80 \times 25 \mathrm{~cm}$, with

Table 1. Physical and chemical properties of the soil used to grow the Tropical Plus ${ }^{\circledR}$ hybrid corn (Syngenta) in a greenhouse on the IF Goiano Urutaí campus, Goiás State, Brazil

\begin{tabular}{|c|c|c|c|c|c|}
\hline \multicolumn{6}{|c|}{ Physical properties } \\
\hline Deep & Coarse sand & Thin sand & Silte & Clay & \multirow{2}{*}{ Textural Class } \\
\hline (cm) & \multicolumn{4}{|c|}{$\mathrm{g} \mathrm{kg}^{-1}$} & \\
\hline $0-20$ & 275 & 324 & 241 & 160 & sandy franc \\
\hline $21-40$ & 329 & 283 & 202 & 186 & sandy franc \\
\hline \multicolumn{6}{|c|}{ Chemical properties } \\
\hline Deep & $\mathrm{pH}$ & MO & $P_{\text {resina }}$ & $\mathrm{H}+\mathrm{Al}$ & K \\
\hline$(\mathrm{cm})$ & $\mathrm{CaCl}_{2}$ & $\mathrm{~g} \mathrm{dm}^{-3}$ & $\mathrm{mg} \mathrm{dm}^{-3}$ & & $\mathrm{mmol}_{\mathrm{c}} \mathrm{dm}^{-3}$ \\
\hline $0-20$ & 6.0 & 24 & 300 & 21 & 4.98 \\
\hline $21-40$ & 5.7 & 16 & 280 & 20 & 4.34 \\
\hline Deep & $\mathrm{Ca}$ & $\mathrm{Mg}$ & SB & СTC & V \\
\hline$(\mathrm{cm})$ & \multicolumn{4}{|c|}{$\mathrm{cmol}_{\mathrm{c}} \mathrm{dm}^{-3}$} & $\%$ \\
\hline $0-20$ & 57 & 22 & 84 & 104 & 80 \\
\hline $21-40$ & 55 & 14 & 73 & 93 & 78 \\
\hline
\end{tabular}

Report issued by the Laboratório Agropecuário LTDA (SOLOGRIA), Goiânia municiplaity, Goiás State, Brazil. 
three seeds per hole, $2 \mathrm{~cm}$ deep. The fertilization was carried out following the recommendations of Trani et al. (2011).

The experiment design was a randomized complete block with subdivided plots in a $4 \times 4$ factorial scheme, with four concentrations of potassium silicate $\left(0,6,12\right.$ and $24 \mathrm{~L}_{\text {of }} \mathrm{K}_{2} \mathrm{SiO}_{3}$ ha $\left.^{-1}\right)$ and four soil water tensions $(15,30,45$ and $60 \mathrm{kPa})$, totaling 16 treatments, with four replications. The experiment consisted of four useful beds (the experiment blocks) with two planting lines per set, except for the borderlines, which were placed at the lateral ends of the greenhouse with just one planting line. Each planting line received an irrigation lateral line, a drip tube and auto-compensated driplines spaced $0.3 \mathrm{~m}$ apart, totaling 8 useful lateral lines and two located in the margins.

The soil adaptation was done by plowing with a mini motorized tractor, model TC 14, 14 HP (Yanmar Agritech $\left.{ }^{\circledR}\right)$ with a rotary hoe. The beds were $7 \mathrm{~m}$ long and $1 \mathrm{~m}$ wide and had manually hoed, totaling 16 beds throughout the experiment.

A drip irrigation system was used, where each planting line received a $16 \mathrm{~mm}$ lateral irrigation line, with emitters spaced every $0.30 \mathrm{~m}$. The emitters provided a flow of $1.4 \mathrm{~L} \mathrm{~h}^{-1}$ with a service pressure of $1 \mathrm{kgf}$ $\mathrm{cm}^{-2}$. The pumping system consisted of a $1 \mathrm{HP}$ motor pump assembly. The fertilizer injection was carried out using the suction system of the pumping set, as pushed by a set of manual controlling valves. Soon after the pumping system was installed, a 120 Mesch screen, in addition to recording the pressure of the irrigation system. A water distribution uniformity test was executed following recommendations of Borssoi et al. (2012) after the irrigation system was installed. The previously calculated water distribution uniformity was $97 \%$.

The irrigation management was done with tensiometry using soil water retention curves (Tahir et al., 2012) and adjusted by the model proposed by Van Genuchten (1980) with the aid of the Soil Water Retention Curve (SWRC ${ }^{\circledR}$ software) version 3.0 (Dourado-Neto et al., 2000). Two puncture tensiometers at depths of $20 \mathrm{~cm}$ and $40 \mathrm{~cm}$ were installed to monitor the soil water tension for each experimental plot (totaling 32 tensiometers). The readings of the soil water tension values, quantified by the tensiometers, were measured using a digital tensometer (SondaTerra ${ }^{\circledR}$ model).
In the first $30 \mathrm{~d}$ after planting, the same irrigation management was used for all treatments in order to assure the natural establishment of the plants. The irrigation was si milar for all plots with permanent soil moisture control at near field capacity. In the first two days after seeding, a $20 \mathrm{~mm}$ blade was applied, followed by daily levels close to $2 \mathrm{~mm}$ according to the soil water retention curve in order to maintain the soil at close to the mean matric potential $(-10 \mathrm{kPa})$.

The potassium silicate was applied via foliar sprayings in the subplots with the help of a manual action costal sprayer (20 L). Drift protection was used to ensure maximum application precision and to avoid contamination of the adjacent subplots, which did not receive the doses of potassium silicate. An aggregate of four applications was done throughout the experiment.

Throughout the sweet corn plant cycle, cultural treatments were performed, such as cutting of plants and leaving a single plant per hole. The dominance of invasive plants was dealt with during the crop cycle through manual weeding. The phytosanitary control was done according to the need for prevention and control throughout the experiment.

All production parameters were quantified at $95 \mathrm{~d}$ after planting, in accordance with the average cycle of the Tropical Plus ${ }^{\circledR}$ hybrid, which is earlier than that of the common corn (Okumura et al., 2013). The following plant parameters were quantified: $1^{\text {st }}$ ear $(\mathrm{cm})$ height, $2^{\text {nd }}$ ear $(\mathrm{cm})$ height, ear length with $(\mathrm{cm})$ and without straw $(\mathrm{cm})$, ear diameter with $(\mathrm{cm})$ and without straw $(\mathrm{cm})$, ear weight with $(\mathrm{cm})$ and without straw $(\mathrm{cm})$, cob diameter $(\mathrm{cm})$, cob fresh weight (g), number of rows per cob, unit grain depth ( $\mathrm{mm}$ ), unit grain width ( $\mathrm{mm})$, fresh $(\mathrm{g})$ and dry $(\mathrm{mg})$ weight of total grains per cob, fresh (g) and dry (mg) weight of a unit cob, fresh ( $\mathrm{g}$ ) and dry (mg) weight of total straw per plant, fresh (g) and dry (mg) stem weight, fresh (g) and dry (mg) weight of all leaves per plant, number of grains per row per ear, ear yield $\left(t h^{-1}\right)$, grain yield $\left(t \mathrm{ha}^{-1}\right)$ and industrial yield $\left(\mathrm{t} \mathrm{ha} \mathrm{a}^{-1}\right)$.

All quantified data were checked for assumptions with analysis of variance. The normality was verified with the Lilliefors adherence test and, in a complementary way, visually using the symmetry of the histogram obtained by the SAEG (System of Statistical and Genetic Analysis) (Ribeiro and Melo, 2009). According to this procedure, all the quantified variables followed normal distribution and, therefore, 
the values of their averages, as disclosed in the figures and tables, were presented in full, without the need for transformation.

After confirmation of the implication (or not) of the factors under interaction or alone according to the ANOVA with a factorial arrangement, the means were compared using the Tukey test at the $5 \%$ probability level. Statistical analyzes (ANOVA and means tests) were done with SAEG, while the images were constructed in SigmaPlot ${ }^{\circledR}$, v. 11 (Systat Software Inc).

\section{RESULTS}

The soil water tensions and potassium silicate doses under interaction did not affect the yield parameters $1^{\text {st }}$ ear height $(\mathrm{F}=0.20, \mathrm{gl}=36, P>0.05, \mathrm{CV}=10$, $(\mathrm{F}=1.24, \mathrm{gl}=36, P=0.04, \mathrm{CV}=9.42)), 2^{\text {nd }}$ ear height $(\mathrm{F}=0.18, \quad(\mathrm{~F}=1.34, \quad \mathrm{gl}=36, \quad P=0.25, \quad \mathrm{CV}=5.68))$, stem-to-straw diameter $(\mathrm{F}=1.24, \mathrm{gl}=(\mathrm{F}=1.00, \mathrm{gl}=36$, $P=0.45, \mathrm{CV}=20.25)$, grain depth $(\mathrm{F}=0.30, \mathrm{CV}=4.03)$ $(\mathrm{F}=0.38, \quad \mathrm{gl}=36, \quad P>0.05, \quad \mathrm{CV}=12.41)$, fresh (g/ $\mathrm{F}=0.66, \mathrm{gl}=36, P>0.05, \mathrm{CV}=14.45)$ and dry $(\mathrm{F}=0.37$, $\mathrm{gl}=36, P>0.05, \mathrm{CV}=13.26),(\mathrm{F}=3.40, \mathrm{gl}=36, P=0.41$, $\mathrm{CV}=10.12)$ grain weight, fresh weights $(\mathrm{F}=0.96$, $\mathrm{gl}=36, P>0.05, \mathrm{CV}=11, \mathrm{~F}=0.67, \mathrm{gl}=36, P=0.05$, $\mathrm{CV}=14.06)$, fresh $(\mathrm{F}=0.67, \mathrm{CV}=28.07)$ and dry $(\mathrm{F}=1.29, \mathrm{gl}=36, P=0.27, \mathrm{CV}=21.08)$ stem weight, fresh weight $(\mathrm{F}=0.84, \mathrm{gl}=36, P>0 \quad(\mathrm{~F}=1.68, \mathrm{gl}=36$, $P=0.12, C V=11.45)$ ), number of grains per row $(\mathrm{F}=0.73, \mathrm{gl}(\mathrm{F}=0.66, P=0.05, \mathrm{CV}=14.45))$ and industrial yield $(\mathrm{F}=0.05, \mathrm{CV}=7.79) 51, \mathrm{gl}=36, P>0.05$, $\mathrm{CV}=12.97)$, isolated or not.

The parameters spike weight $(\mathrm{F}=3.41, \mathrm{gl}=36, P=0.02$, $\mathrm{CV}=9.68)$, without straw $(\mathrm{F}=4.13, \mathrm{gl}=36, P=0.01$, $\mathrm{CV}(\mathrm{F}=6.52, \mathrm{gl}=36, P=0.04, \mathrm{CV}=9.81)$, fresh cob weight $(\mathrm{F}=(\mathrm{F}=3.46, \mathrm{gl}=36, P=0.02, \mathrm{CV}=5.85)$ and ear yield ( $\mathrm{F}=3.41$, (Fig. 1$)$ were affected by the soil water stress (Fig. 1).

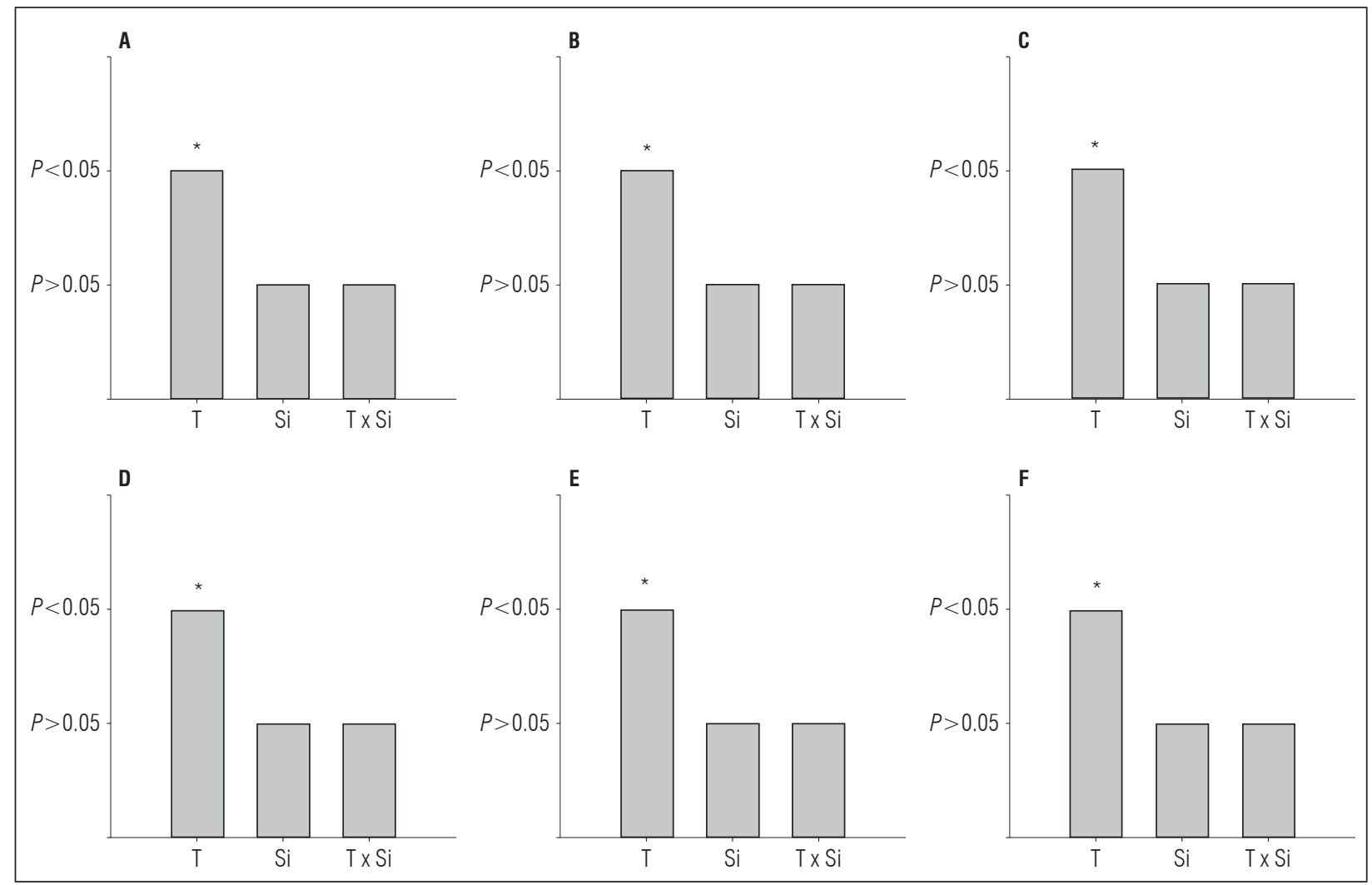

Figure 1. Summary of the ANOVA (factorial with subdivided plots) of the soil water tensions (T) (plots) and potassium silicate doses ( $\mathrm{Si}$ ) (subplots), isolated or under interaction ( $\mathrm{T} \times \mathrm{Si}$ ), for the significant production parameters (Test $\mathrm{F}$ ) of the sweet corn (Zea mays var. Saccharata) hybrid Tropical Plus ${ }^{\circledR}$. Instituto Federal Goiano, Urutaí, Goiás, Brazil. A: spike weight with straw; B: spike weight without straw; C: corn cob diameter; D: corn cob fresh weight; E: number of rows per cob; F: spike yield. 
Higher values for shank weight, with and without straw, were reached at 15 and $30 \mathrm{kPa}$, as compared to the 45 and $60 \mathrm{kPa}$ voltages (Fig. 2). The diameter of the cob, fresh weight of the cob and number of rows per spike were also higher with the tensions between 15 and $30 \mathrm{kPa}$ (Tab. 2). The tension of $60 \mathrm{kPa}$ had lower values for these parameters, including the ear yield (Tab. 2).

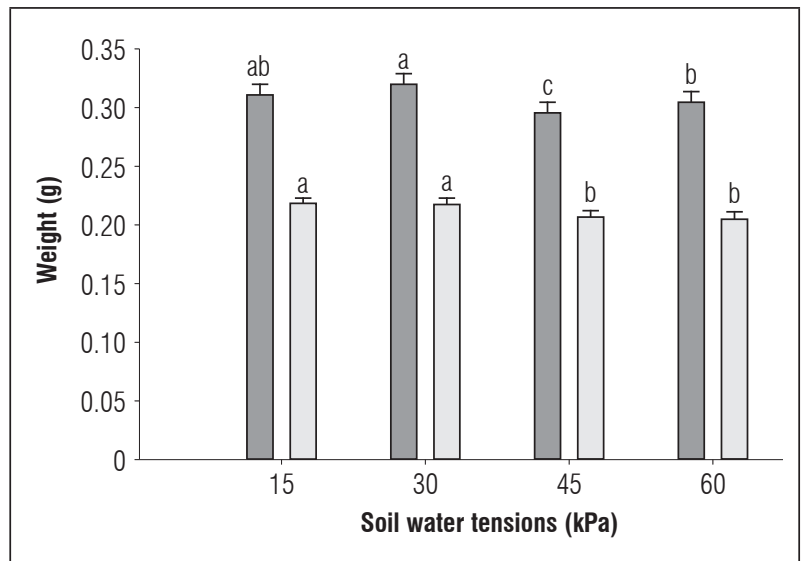

Figure 2. Weight (mean \pm SEM) of sweet corn (Zea mays var. Saccharata) Tropical Plus ${ }^{\circledR}$ hybrid spikes with straw (dark gray bars) and without straw (light gray bars) under the effect of soil water tensions (kPa). Instituto Federal Goiano, Urutaí, Goiás, Brazil. Means with different letters, for each variable, indicate significant differences according to the Tukey test $(P \leq 0.05)$.

\section{DISCUSSION}

The lack of effect of the soil water tensions and potassium silicate doses, isolated or under interaction, was observed on most yield parameters. The interaction between these two factors should be important for maize plants as a result of giving resistance to water stress, as previously reported (Marques et al., 2016). The absence of significant effects of the Si dose factor (isolated) on the productive parameters of the sweet corn did not necessarily imply that it had no influence on the results. The physiological and biochemical effects of Si under stress conditions such as water balance, reduction of oxidative stress and maintenance of adequate mineral absorption by the root system (Zhu and Gong, 2014) were entirely ignored in the present study. The fact that the water stress did not affect most sweet corn yield variables may have been due to the physiological and biochemical effect from the $\mathrm{Si}$ in the sweet corn plants. Si can mitigate water stress effects on plants of economic importance, such as Zea mays (Gao et al., 2006). This may have partially been noted in the present study with the absence of a soil water tension effect in most production parameters that normally respond to water stress.

Differences in the yield parameters were more evident when different maize genotypes were compared (Santos et al., 2004). The similar effect of the genetic configuration of the sweet corn Tropical Plus ${ }^{\circledR}$ hybrid in all treatments may also be responsible for the lack of effect on the evaluated yield parameters. Zea mays is relatively tolerant to water stress during the vegetative stage, but extremely sensitive if the stress condition persists during the reproductive stage (Song et al., 2010). Different soil water stresses were managed in the sweet corn plants during their entire vegetative and reproductive cycle, including in the stage between pre-flowering and grain filling. This stage is critical, where the plant can no longer satisfactorily recover from a water stress experienced in previous stages (Çakir, 2004). Therefore, the hypothesis that sweet corn adult plants have attenuated the negative effects of water stress experienced during its vegetative phase must be discarded. This would be an effective strategy for the plant to overcome stress

Table 2. Soil water tensions (SWT), cob diameter (CD), cob fresh weight (CFW), Rows number per ear (RNEAR) and spike yield (SY) (SWST) (mean \pm EP1) of sweet corn (Zea mays var. Saccharata) Tropical Plus ${ }^{\circledR}$ hybrid (Syngenta) under different soil water stresses tensions (kPa). Federal Goiano Institute, Urutaí, Goiás, Brazil

\begin{tabular}{|c|c|c|c|c|}
\hline $\begin{array}{c}\text { SWT } \\
(\mathrm{kPa})\end{array}$ & $\begin{array}{c}\text { CD } \\
(\mathrm{cm})\end{array}$ & $\begin{array}{c}\text { CFW } \\
(\mathrm{g})\end{array}$ & RNEAR & $\begin{array}{c}\text { SY } \\
\left.(\mathrm{t} \mathrm{ha})^{-1}\right)\end{array}$ \\
\hline 15 & $33.74 \pm 0.27 \mathrm{a}$ & $0.216 \pm 0.05 \mathrm{a}$ & $15.81 \pm 0.19 \mathrm{a}$ & $27.46 \pm 0.80 \mathrm{~b}$ \\
\hline 30 & $33.11 \pm 0.28 \mathrm{~b}$ & $0.219 \pm 0.01 \mathrm{a}$ & $15.60 \pm 0.22 \mathrm{ab}$ & $28.28 \pm 0.82 \mathrm{a}$ \\
\hline 45 & $32.56 \pm 0.30 \mathrm{c}$ & $0.204 \pm 0.09 \mathrm{~b}$ & $15.50 \pm 0.25 \mathrm{ab}$ & $26.88 \pm 0.87 \mathrm{c}$ \\
\hline 60 & $32.91 \pm 0.42 \mathrm{~d}$ & $0.184 \pm 0.07 \mathrm{c}$ & $15.35 \pm 0.20 \mathrm{~b}$ & $26.10 \pm 0.69 \mathrm{~d}$ \\
\hline
\end{tabular}

Means with different letters, per column, indicate significant differences according to the Tukey test $(P \leq 0.05)$. 
conditions experienced in the vegetative stage without reducing yield parameters in the reproductive stage (Ferreira et al., 2011).

The effect of the soil water tensions, with lower values for the sweet corn ear weight, with and without straw, at the higher ones, agrees with reports that indicated sensitivity to water stress (Almeida et al., 2016). Lower values for cob diameter and cob fresh mass under water stress conditions was reported (Parizi et al., 2009). These variables are strong yield indicators in corn crops because, the greater the corn mass, the greater the grain mass is (Shaheenuzzamn et al., 2015). This may also explain, in part, the significant differences for cob diameter and fresh weight as productivity spiked with the different soil water tensions. However, it does not fully explain why this factor did not affect the other yield parameters of the corn ear yield. The soil water tension effect may have been compensated for by the potassium silicate doses even though this factor (Si doses) did not affect most yield production parameters.

The lowest variation in the means of rows per spike, among the parameters affected by soil water tensions, may have been due to the genetic component of the evaluated Tropical Plus ${ }^{\circledR}$ hybrid, agreeing with other studies that also did not report differences (Ferreira et al., 2011). The decreasing number of rows per spike as the soil water stress increased was also seen in a study that evaluated the effect of different irrigation levels and calcium silicate doses on the common corn material BR 106 (Marques, 2013). The average number of rows per ear of sweet corn (independent of the soil water tensions content) was close to the 16 rows per spike that sees good acceptance on the Brazilian consumer market, reinforcing the genetic resistance of the Tropical Plus ${ }^{\circledR}$ hybrid even with water stress (Pereira et al., 2002).

The maximum productivity of the Tropical Plus ${ }^{\circledR}$ hybrid ( $28 \mathrm{t} \mathrm{ha}^{-1}$ at $\left.30 \mathrm{kPa}\right)$ was higher than that indicated by the Syngenta company in Brazil ( $\sim 17$ $\mathrm{t} \mathrm{ha}^{-1}$ ) (www.syngenta.com.br). This value varies when increasing crop yields while increasing the Tropical Plus ${ }^{\circledR}$ hybrid plant population from 40,000 to 100,000 plants/ha with a maximum yield of $\sim 9$ $\mathrm{t} \mathrm{ha}^{-1}$ for winter-spring cultivations and $\sim 12 \mathrm{t} \mathrm{ha}^{-1}$ for summer crops under field conditions (Souza et al. 2013a; Souza et al. 2003b). The Vivi, Tropical Plus ${ }^{\circledR}$ and Dow SWB 551 hybrids, with 5.73, 5.35 and $2.0 \mathrm{t}$ ha $^{-1}$, respectively, have also had similar ear yield production in the field (Teixeira et al., 2009). Differences in productivity results may be explained by the fact that this experiment was conducted in a greenhouse, reducing the influence of biotic and abiotic effects on the sweet corn plant production (Rosa et al., 2016).

The sweet corn cultivars KSC403, Merit and Obsession in Iran (Mashhad) had a similar response pattern, with decreasing growth under water stress condition (Tafrishi et al. 2013). The yield parameters had high sensitivity to the water stress, being a very responsive component in water stress evaluations in Zea mays species (Moradi et al. 2012).

Water stress reduces sweet corn plant productivity with losses to the corn agribusiness in Brazil. The role of silicon as an elicitor of resistance against water stress effects has been reported, and, for this reason, the non-significant effect of the $\mathrm{Si}$ (isolated or under interaction with the soil water tensions) should not be neglected. The spraying of potassium silicate throughout the vegetative stage on the sweet corn plants allowed for the absorption of silicon and its storage and transport to the plant yield structures (Mitani et al., 2009). This indicates a higher plant affinity with silicon in the vegetative stage than in the reproductive stage. Silicon may be important in post-harvest tomatoes (Marodin et al., 2016), another important plant in Cerrado biome agriculture.

\section{ACKNOWLEDGMENTS}

The authors thank the "Instituto Federal Goiano (IF Goiano), Campus Urutaí", the "Conselho Nacional de Desenvolvimento Científico e Tecnológico (CNPq)", Conservas Oderich SA, à "Fundação de Amparo à Pesquisa do Estado de Goiás (FAPEG)" and the "Programa de Pós-Graduação em Olericultura do IF Goiano, Campus Morrinhos".

Conflict of interests: this manuscript was prepared and reviewed with the participation of all authors, who declare that there exists no conflict of interest that puts at risk the validity of the presented results.

\section{BIBLIOGRAPHIC REFERENCES}

Almeida, B.M. 2016. Déficit e excesso hídrico na cultura do milho (Zea mays L.) em ambiente protegido. $\mathrm{PhD}$ thesis. Escola Superior de Agricultura "Luiz de Queiroz", Universidade de São Paulo, Piracicaba, Brazil.

Barbieri, V.H.B., J.M.Q. Luz, C.H. Brito, J.M. Duarte, L.S. Gomes, and D.G. Santana. 2005. Produtividade e 
rendimento industrial de híbridos de milho doce em função de espaçamento e populações de plantas. Hortic. Bras. 23(3), 826-830. Doi: 10.1590/ S0102-05362005000300027

Berlato, M.A., H. Farenzena, and D.C. Fontana. 2005. Associação entre El Niño oscilação Sul e a produtividade do milho no estado do rio Grande do Sul. Pesq. Agropec. Bras. 40(5), 423-432. Doi: 10.1590/ S0100-204X2005000500001

Borssoi, A.L., M.A. Vilas Boas, M. Reisdörfer, R.H. Hernández, and F.A.C. Follador. 2012. Water application uniformity and fertigation in a dripping irrigation set. Eng. Agríc. 32(4), 718-726. Doi: 10.1590/ S0100-69162012000400011

Brunini, O., J. Zullo, H.S. Pinto, E.D. Assad, E. Sawazaki, A.P. Duarte, and M.E.Z. Patterniani. 2001. Riscos climáticos para a cultura do milho no estado de São Paulo. Rev. Bras. Agrometeorol. 9(3), 519-526.

Çakir, R. 2004. Effect of water stress at different development stages on vegetative and reproductive growth of corn. Field Crops Res. 89(1), 1-16. Doi: 10.1016/j. fcr.2004.01.005

Doto, V.C., H. Yacouba, D. Niang, R. Lahmar, and E.K. Agbossou. 2015. Mitigation effect of dry spells in Sahelian rainfed agriculture: case study of supplemental irrigation in Burkina Faso. Afr. J. Agric. Res. 10(16), 1863-1873. Doi: 10.5897/AJAR2015.9639

Dourado-Neto, D., D.R. Nielsen, J.W. Hopmans, K. Reichardt, and O.O.S. Bacchi. 2000. Software to model soil water retention curves (SWRC, version 2.00). Sci. Agric. 57(1), 191-192. Doi: 10.1590/ S0103-90162000000100031

Embrapa, Empresa Brasileira de Pesquisa Agropecuária. 1999. Sistema brasileiro de classificação de solos. Brasília.

Ferreira, M.G.P., M.E.B. Brito, F.B. Costa, G.D.A. Filho, and F.C.G. Alvino. 2011. Aspectos químicos e físicos dos grãos de milho doce sob estresse hídrico. Rev. Bras. Agrotecnol. 1(1), 1-6.

Gao, X., C. Zou, L. Wang, and F. Zhang. 2006. Silicon decreases transpiration rate and conductance from stomata of maize plants. J. Plant. Nutr. 29(9), 1637-1647. Doi: 10.1080/01904160600851494

Korndörfer, G.H., H.S. Pereira, and M.S. Camargo. 2004. Silicatos de cálcio e magnésio na agricultura. $3^{\text {th }} \mathrm{ed}$. Bol. Téc. 1. UFU; ICIAG, Uberlândia, Brazil.

Li, W., P. Zhang, J. Ye, L. Li, and P.A. Baker. 2011. Impact of two different types of El Niño events on the Amazon climate and ecosystem productivity. J. Plant Ecol. 4(12), 91-99. Doi: 10.1093/jpe/rtq039

Ma, J.F. and N. Yamaji. 2006. Silicon uptake and accumulation in higher plants. Trends Plant Sci. 11(8), 392-397. Doi: 10.1016/j.tplants.2006.06.007

Marodin, J.C., J.T.V. Resende, R.G.F. Morales, M.V. Faria, A.R. Trevisam, A.S.T. Figueiredo, and D.M. Dias.
2016. Tomato post-harvest durability and physicochemical quality depending on silicon sources and doses. Hortic. Bras. 34(3), 361-366. Doi: 10.1590/ S0102-05362016003009

Marques, D.J. 2013. Proporções de silicato e carbonato de cálcio no crescimento, nutrição mineral e eficiência do uso da água por plantas de milho sob estresse hídrico. $\mathrm{PhD}$ thesis. Universidade Federal de Lavras, Lavras, Brazil.

Marques, D.J., M.M. Ferreira, A.K.S. Lobato, W.A. Freitas, J.A. Carvalho, E.D. Ferreira, and F. Broetto. 2016. Potential of calcium silicate to mitigate water deficiency in maize. Bragantia 75(3), 275-285. Doi: 10.1590/1678-4499.446

Mitani, N., N. Yamaji, and J.F. Ma. 2009. Identification of maize silicon influx transporters. Plant Cell Physiol. 50(1), 5-12. Doi: 10.1093/pcp/pcn110

Montero, J., A. Martínez, M. Valiente, M.A. Moreno, and J.M. Tarjuelo. 2013. Analysis of water application costs with a centre pivot system for irrigation of crops in Spain. Irrigation Sci. 31(3), 507-521. Doi: 10.1007/ s00271-012-0326-4

Moradi, H., G.A. Akbari, S.K. Khorasani, and H.A. Ramshini. 2012. Evaluation of drought tolerance in corn (Zea mays L.) new hybrids with using stress tolerance indices. Eur. J. Sust. Dev. 1(3), 543-560.

Okumura, R.S., D.C. Mariano, A.A.N. Franco, P.V.C. Zaccheo, and T.O. Zorzenoni. 2013. Sweet corn: Genetic aspects, agronomic and nutritional traits. Appl. Res. Agrotecnol. 6(1), 105-114. Doi: 10.5935/PAeT. V6.N1.13

Oliveira, L.A. and N.M. Castro. 2002. Ocorrência de sílica nas folhas de Curatella americana L. e de Davilla elliptica St. Hil. Rev. Horiz. Cient. 4, 1-16.

Parizi, A.R.C., A.D. Robaina, A.C.S. Gomes, F.C. Soares, C.J. Ramão, M.X. Peiter, and L. Calegaro. 2009. Efeito de diferentes estratégias de irrigação suplementar sobre a produção de grãos e seus componentes na cultura do milho. Irriga 14(3), 254-267. Doi: 10.15809/ irriga.2009v14n3p254-267

Pereira Filho, I.A., J.C. Cruz, and E.E.G. Gama. 2002. Cultivares de milho para o consumo verde. pp. 17-30. In: Pereira Filho, I.A. (ed.). O cultivo do milho verde. Embrapa Milho e Sorgo, Sete Lagoas, Brazil.

Ribeiro Júnior, J.I. and A.L.P. Melo. 2009. Guia prático para utilização do SAEG. UFV, Viçosa, Brazil.

Rosa, R., E. Kosterna-Kelle, J. Franczuk, and A. Zaniewicz -Bajkowska. 2016. The influence of weather conditions of eastern Poland on sweet corn yields and length of growing season. J. Ecol. Eng. 17(4), 273-279. Doi: 10.12911/22998993/64501

Santos, P.H.A.D., M.G. Pereira, R.S. Trindade, K.S. Cunha, G.C. Entringer, and J.C.F. Vettorazzi. 2014. Agronomic 
performance of super-sweet corn genotypes in the North of Rio de Janeiro. Crop. Breed. Appl. Biotechnol. 14(1), 8-14. Doi: 10.1590/S1984-70332014000100002

Shaheenuzzamn, M., R.R. Saha, B. Ahmed, J. Rahman, and M. Salim. 2015. Green cob and fodder yield of sweet corn as influenced by sowing time in the hilly region. Bangladesh J. Agril. Res. 40(1), 61-69. Doi: 10.3329/ bjar.v40i1.23760

Song, Y., C. Birch, S. Qu, A. Doherty, and J. Hanan. 2010. Analysis and modeling of the effects of water stress on maize growth and yield in dryland conditions. Plant Prod. Sci. 13(2), 199-208. Doi: 10.1626/pps.13.199

Souza, R.S., P.S. Vidigal Filho, C.A. Scapim, O.J. Marques, D.C. Queiroz, R.S. Okumura, D.L. Reche, and V.B. Cortinove. 2013a. Produtividade e qualidade do milho doce em diferentes populações de plantas. Semina: Ciênc. Agrár. 34(3), 995-1010. Doi: 10.5433/1679-0359.2013v34n3p995-1010

Souza, R.S., P.S. Vidigal Filho, C.A. Scapim, O.J. Marques, D.C. Queiroz, R.S. Okumura, J.V. José, and R.V. Tavore. 2013b. Elementos de produção de milho doce em diferentes densidades populacionais. Comun. Sci. 4(3), 285-292.

Tafrishi, S.G., A. Ayenehband, H. Tavakoli, S.K. Khorasani, and M. Joleini. 2013. Impacts of drought stress and planting methods on sweet corn yield and water use efficiency. J. Plant Physiol. Breed. 3, 23-31.
Tahir, M., A.U. Hassan, Z.A. Zahir, and K.U. Rehman. 2012. Modeling water retention capacity and hydraulic properties of a manure-amended loam soil and its effect on wheat and maize yield. Int. J. Agric. Biol. 14, 492-498.

Takahashi, E., J.F. Ma, and Y. Miyake. 1990. The possibility of silicon as an essential element for higher plants. Comments Agric. Food Chem. 2, 99-122.

Teixeira, F.F., I.R.P. Sousa, E.E.G. Gama, C.A.P. Pacheco, S.N. Parentoni, M.X. Santos, and W.F. Meirelles. 2001. Avaliação da capacidade de combinação entre linhagens de milho doce. Ciênc. Agrotec. 25, 483-488.

Teixeira, F.F., E.E.G. Gama, and F.M. Costa. 2009. Aspectos agronômicos e de qualidade de espiga em famílias endogâmicas de milho doce. Cir. Téc. 121, Embrapa, Sete Lagoas, Brazil.

Trani, P.E., S.W. Tiveli, and O.A. Carrijo. 2011. Fertirrigação em hortaliças. $2^{\text {nd }}$ ed. Série Tecnologia APTA. Bol. Téc. IAC 196. Instituto Agronômico, Campinas, Brazil.

Van Genuchten, M.T. 1980. A closed-form equation for predicting the hydraulic conductivity of unsaturated soils. Soil Sci. Soc. Am. J. 44(5), 892-898. Doi: 10.2136/ sssaj1980.03615995004400050002x

Zhu, Y. and H. Gong. 2014. Beneficial effects of silicon on salt and drought tolerance in plants. Agron. Sustain. Dev. 34(2), 455-472. Doi: 10.1007/s13593-013-0194-1 